\title{
Short Communication: Single nucleotide polymorphism in C-type lysozyme gene and its correlation with Aeromonas hydrophila resistance in African catfish Clarias gariepinus
}

\author{
HASAN NASRULLAH ${ }^{1}$, YANTI INNEKE NABABAN ${ }^{1}$, IKA SAFITRI ${ }^{1}$, DWI HANI YANTI ${ }^{2}$, SRI NURYATI $^{1}$, \\ MUHAMMAD ZAIRIN JUNIOR ${ }^{1}$, ALIMUDDIN ALIMUDDIN ${ }^{1, \boldsymbol{v}}$ \\ ${ }^{1}$ Department of Aquaculture, Faculty of Fisheries and Marine Sciences, Institut Pertanian Bogor. Jl. Agatis, IPB Dramaga Campus, Bogor 16680, \\ West Java, Indonesia. Tel. +62-251-8622755, Fax.: +62-251-8622941, `email: alimuddin@apps.ipb.ac.id \\ ${ }^{2}$ National Center for Freshwater Aquaculture. Jl. Selabintana No. 37, Sukabumi 43114, West Java, Indonesia
}

Manuscript received: 23 October 2019. Revision accepted: 28 December 2019.

\begin{abstract}
Nasrullah N, Nababan YI, Safitri I, Yanti DH, Nuryati S, Zairin Junior M, Alimuddin A. 2020. Short Communication: Single nucleotide polymorphism in C-type lysozyme gene and its correlation with Aeromonas hydrophila resistance in African catfish Clarias gariepinus. Biodiversitas 21: 311-317. The chicken-type lysozyme (LYSC) gene has been demonstrated to play important roles in the fish protection system against bacterial infection. In this present study, we aimed to identify the single nucleotide polymor phism (SNP) within the LYSC gene of African catfish Clarias gariepinus and its possible association with Aeromonas hydrophila resistance, a major pathogenic bacterium in African catfish. The gDNA of the African catfish LYSC coding sequence was 1559 bp long, comprising of four exons and three introns. Six SNPs were identified in African catfish LYSC, namely SNP1-6. After the A. hydrophila challenge, we regarded the surviving individuals after the infection as the resistant group and the dead fish as the susceptible group. High-resolution melting (HRM) analysis on SNP2 revealed that the allele frequencies of TT, CC, and TC were of $27.78 \%, 5.55 \%$, and $66.67 \%$ in the resistant group, while the frequencies of TT, CC, and TC were $16.67 \%, 27.78 \%$, and $55.55 \%$ in the susceptible group, respectively. The expression of LYSC and other immune-genes in the resistant group was also higher in the liver, head kidney, and spleen. These results indicated that the LYSC gene might play an essential role in bacterial resistance, and the SNP2 within the LYSC gene may be associated with the resistance to $A$. hydrophila in African catfish.
\end{abstract}

Keywords: Aeromonas hydrophila, African catfish, disease resistance, lysozyme gene, SNP

\section{INTRODUCTION}

The African catfish (Clarias gariepinus Bloch, 1794) is an important aquaculture species in the world that mainly produced in African and Asian countries, including Indonesia (Ekasari et al. 2016; Dauda et al. 2018). The African catfish production has increased significantly through intensive fish culture practices, thus consequently exposes the cultured fish to common stressors and diseases (Shoko et al. 2016; Yarahmadi et al. 2016). One of the most commonly occurred diseases in African catfish is motile aeromonad septicemia (MAS) caused by Aeromonas hydrophila infection. This Gram-negative bacterium has caused high mortality in African catfish and other freshwater species, leading to substantial economic loss (Angka et al. 1995; Hanson et al. 2014). Most cases of MAS can be correlated to various factors such as infection, and environmental stress, and sometimes associated with nutritional stress and handling stress (Hanson et al. 2014). Recently, our research has begun to focus on breeding African catfish resistant to A. hydrophila. However, little information is available about genes related to $A$. hydrophila resistance in African catfish.

Lysozyme has crucial roles in fish early defense system and innate immunity. This hydrolase enzyme catalyzes the hydrolysis of $\beta$ - $(1,4)$-glycosidic bonds between the $\mathrm{N}$ acetyl glucosamine and $\mathrm{N}$-acetyl muramic acid in the peptidoglycan layer of bacterial cell walls, thus possess bacteriolytic activity against Gram-positive and Gramnegative (Saurabh dan Sahoo 2008). Generally, among the vertebrate and teleost fish, lysozyme is mostly found in two types: chicken-type (LYSC) and goose-type (LYSG) (Callewaert dan Michiels 2010; Buonocore et al. 2014). Both lysozymes gene has been demonstrated to play essential roles as the immune defense in many fish species (Mohanty dan Sahoo 2010; Pridgeon et al. 2013; Wei et al. 2014; Di Falco et al. 2017). The involvement of the LYSC in the protection against bacterial infection has been reported in fish species, such as resistant families of Atlantic salmon against Piscirickettsia salmonis infection (Dettleff et al. 2015), channel catfish against Edwardsiella ictaluri (Wang et al. 2013), Darby's sturgeon and Qihe crucian carp against A. hydrophila (Wang et al. 2016; Zhang et al. 2018), Moreover, the single nucleotide polymorphisms (SNPs) in LYSC gene have been characterized in several fish species, such as Asian seabass (Fu et al. 2013) and Japanese flounder (Liu et al. 2017) and identified as potential markers for bacterial-resistance 
in fish. However, such studies in African catfish are still limited. In this present study, we aimed to identify the single nucleotide polymorphism (SNP) within the LYSC gene of African catfish and studied its possible association with Aeromonas hydrophila resistance.

\section{MATERIALS AND METHOD}

\section{Isolation of LYSC Genomic DNA sequences}

To obtain the genomic sequence of the LYSC gene, primers were designed to amplify the full length of the coding sequence of LYSC mRNA (Genbank accession number: MK344777.1). The forward primer was located from the start codon, and the reverse primer sequence was ended in the stop codon of the coding sequence. BamHI site was added in the forward primer and NdeI site in the reverse primer for future cloning purposes (Table 1). The genomic DNA was extracted from the fin using Gentra® Purgene ${ }^{\circledR}$ Tissue kit (Qiagen, USA) according to the kit manual. PCR amplification was performed in a $50 \mu \mathrm{L}$ of reaction volume consisting of $50 \mathrm{ng}$ of genomic DNA, 10 $\mu \mathrm{M}$ of each primer, and $2 \times$ MyTaq $^{\mathrm{TM}} \mathrm{HS}$ DNA polymerase mix (Bioline, UK). The amplification program consisted of the following steps: $95^{\circ} \mathrm{C}$ for 2 min followed by 35 cycles of $95{ }^{\circ} \mathrm{C}$ for $30 \mathrm{~s}, 60{ }^{\circ} \mathrm{C}$ for $30 \mathrm{~s}$, and $72{ }^{\circ} \mathrm{C}$ for 1 min $30 \mathrm{~s}$, then a final step of $72^{\circ} \mathrm{C}$ for $5 \mathrm{~min}$. The PCR products were purified using Wizard ${ }^{\circledR}$ Genomic DNA Purification kit (Promega, USA) and then sequenced using 3500 Genetic Analyzer (Applied Biosystem, USA). The African catfish LYSC gDNA sequence then compared to other fish species LYSC sequences available at the Genbank database.

\section{Fish and bacterial infection}

African catfish $(6.00 \pm 0.56 \mathrm{~g}, \mathrm{n}=1,000)$ were obtained from the National Centre for Freshwater Aquaculture, Sukabumi, West-Java, Indonesia. The fish were acclimated for one week in a 1,050 L fiber tank. Fish were fed twice with commercial pellets. Feed and fecal wastes were removed daily. No clinical signs of bacterial disease were observed during acclimatization. Pathogenic A. hydrophila was obtained from our lab culture collection. The isolate was characterized using biochemical tests, and the lethal dose 70 (LD70) of the bacteria was determined before the experiment. A. hydrophila was diluted in phosphate buffer saline (PBS) solution in a final concentration of $10^{8} \mathrm{CFU}$ $\mathrm{mL}^{-1}$ based on the LD70 concentration. Before the $A$. hydrophila challenge, the fish was anesthetized with $75 \mathrm{mg}$ $\mathrm{L}^{-1} \mathrm{MS} 222$. Two hundred fish were injected with $0.1 \mathrm{~mL}$ of pathogenic A. hydrophila at LD70 concentration intramuscularly. Sixty fish were injected by $0.1 \mathrm{~mL}$ PBS as a control group. The fish were reared for $24 \mathrm{~h}$ in the $60 \mathrm{~L}$ glass tanks with 20 fish/tank density. After $24 \mathrm{~h}$, we regarded the surviving individuals after the infection as a resistant group and the dead fish as the susceptible group.

\section{qPCR and SNP analysis}

To identify the reference genotype in the LYSC gene, we amplify the gDNA from seven resistant fish, and five susceptible fish then sequenced the PCR products. The LYSC and other immune-related genes: goose-type lysozyme (LYSG), hepcidin (HAMP), and interleukin-1 $\beta$ (IL1B) mRNA expression of the resistant fish were analyzed at $0 \mathrm{~h}$ and $24 \mathrm{~h}$ after bacterial infection to investigate the immunological roles of the gene. Total RNA was extracted from the liver, head-kidney, and spleen of the resistant fish $(n=4)$ and analyzed using the qPCR method. The RNA extraction, cDNA synthesis, and qPCR analysis were conducted according to our previous research (Nasrullah et al. 2019). The $\beta$-actin gene was used for normalization and PBS control at $0 \mathrm{~h}$ as the expression calibrator. The expression data were analyzed using the 2${ }^{\Delta \Delta \mathrm{CT}}$ method (Livak dan Schmittgen 2001).

Table 1. Mortality of $C$. gariepinus $24 \mathrm{~h}$ after challenge with $A$. hydrophila

\begin{tabular}{lcccc}
\hline \multicolumn{1}{c}{ Treatment } & $\begin{array}{l}\text { Number of } \\
\text { challenged } \\
\text { individuals }\end{array}$ & Survived Dead & $\begin{array}{c}\% \\
\text { Mortality }\end{array}$ \\
\hline $\begin{array}{l}\text { A. hydrophila } \\
\text { infection }\end{array}$ & 200 & 49 & 151 & 75.5 \\
PBS control & 60 & 60 & 0 & 0 \\
\hline
\end{tabular}

Table 2. The primer used in this study

\begin{tabular}{|c|c|c|c|c|}
\hline Primer name & Sequence (5' - 3') & Ta $\left({ }^{\circ} \mathrm{C}\right)$ & Application & Reference \\
\hline LYSC F & AAAGGATCCATGAAGGCTTTGGTGTTCTT & 60 & gDNA amplification of LYC coding & MK344777.1 \\
\hline LYSC R & CGATCATATGTTATTAAACTCCACAGCC & & sequence & \\
\hline SNPLYSC F & TTCCATAGTGCTAACGGGTGC & 60 & SNP Genotyping by HRM analysis & This study \\
\hline SNPLYSC R & GCACACTCAACAGCTTTCGC & & & \\
\hline qLYSC F & CGGTATGATCGGTGTGAGCTGG & 60 & qPCR analysis of LYSC & Nasrullah et al. \\
\hline qLYSC R & CGGTTCTGGGCGTTGGTATTGA & & & $(2019)$ \\
\hline qLYSG F & CCTAACTGGCCCAAAGAGCA & 60 & qPCR analysis of LYSG & Nasrullah et al. \\
\hline qLYSG R & CCATACCCTCGTATGTGCGG & & & (2019) \\
\hline qHAMP F & TATCGTCATCATCGCGTGCA & 60 & qPCR analysis of HAMP & MK344776.1 \\
\hline qHAMP R & TCCTTCGCCAATGATGCAGT & & & \\
\hline qIL1B F & TGCAGTGAATCCAAGAGCTACAGC & 60 & qPCR analysis of IL1B & МH341527.1 \\
\hline qIL1B R & CCACCTTTCAGAGTGAATGCCAGC & & & \\
\hline qACTB F & ACCGGAGTCCATCACAATACCAGT & 60 & Internal control, expression & Nasrullah et al. \\
\hline qACTB R & GAGCTGCGTGTTGCCCCTGAG & & normalization & $(2019)$ \\
\hline
\end{tabular}

Note: Restriction sites for future cloning purposes are written in italic 
To examine the association of the SNP with the $A$. hydrophila resistance, we collected fin clips from 36 individuals from each resistant and susceptible group. The potential SNPs were genotyped using qPCR-high resolution melting (HRM) analysis (Reed et al. 2007). The primer for the analysis was designed based on the SNP2 as the potential marker. The HRM analysis was performed in $20 \mu \mathrm{L}$ of the final volume consisting of $4 \mu \mathrm{L}$ gDNA ( $1 \mathrm{ng})$, $0.8 \mu \mathrm{L}$ of each primer $(10 \mathrm{mM}), 10 \mu \mathrm{L}_{\text {SensiFAST }}{ }^{\mathrm{TM}} \mathrm{HRM}$ kit (Bioline, UK), and $4.4 \mu \mathrm{L}$ nucleases free water. The HRM analysis conducted in Rotorgene6000 (Corrbet, USA) machine using the following program: $95{ }^{\circ} \mathrm{C}$ for 5 min followed by 40 cycles of $95^{\circ} \mathrm{C}$ for $15 \mathrm{~s}, 60^{\circ} \mathrm{C}$ for $10 \mathrm{~s}$, and $72{ }^{\circ} \mathrm{C}$ for $10 \mathrm{~s}$, then followed by an increasing temperature $72-92^{\circ} \mathrm{C}$. Melt curves were generated in the HRM analysis module of RotorGeneQ software (Corrbet, USA). The normalized regions were set from $78-79{ }^{\circ} \mathrm{C}$ and 80.93-81.99 ${ }^{\circ} \mathrm{C}$. The samples were assigned to a given genotype by examining the normalized melt curve plots in comparison to the reference genotypes at a $90 \%$ confidence threshold.

\section{RESULTS AND DISCUSSION}

\section{Genomic structure and mRNA expression}

The genomic sequence of African catfish LYSC gene from the transcriptional start site to the transcriptional end site was 1559 bp long, comprising of four exons $(127,159$, 76 and 67 bp, respectively) and three introns (595,104, and $431 \mathrm{bp}$, respectively), as shown in Figures 1 and 2. This result is consistent with other fish species (Hikima et al. 2000; Fu et al. 2013). A phylogenetic tree (Figure S1) was constructed using the African catfish LYSC gDNA and other fish species using the neighbor-joining method. The African catfish LYSC was closely related to the LYSC sequence form other catfish species and located in the different clades with mammals and the goose-type lysozyme gene. The African catfish LYSC gDNA sequence was submitted to the Genbank under accession number: MN562879. Six SNPs were identified in African catfish LYSC. SNP1 was located in intron 1 (gDNA position 292, T/C), SNP2 and SNP3 were in intron 2 (position 889, T/C; and position 920, G/A), and SNP4, SNP5, and SNP6 were in intron 3 (position 1137, G/A; position 1237, G/T; and position $1280 \mathrm{G} / \mathrm{C}$ ). LYSC polymorphism also found in other fish species. Japanese flounder Paralichthys olivaceus has eight polymorphism sites in its LYSC promotor and nine SNPs in the coding region (Liu et al. 2017). Asian seabass has two SNPs in the exon and the intron of the LYSC coding sequence (Fu et al. 2013).

\section{The mRNA expression and SNP associations to the Aeromonas hydrophila resistance}

After the A. hydrophila challenge, the LYSC and other immune related-genes expression levels of resistant fish were higher than susceptible fish in several tissues $(\mathrm{p}<0.05)$, as shown in Figure 3. LYSC, LYSG, and HAMP expression were higher in the liver, head-kidney, and spleen $(\mathrm{p}<0.05)$, since the organs are reported to be the major organs affected by A. hydrophila (Sahoo et al. 1998). The highest expression level of LYSC was observed in the liver, followed by head-kidney and spleen. The upregulation of LYSC and other immune genes expression after bacterial challenge also reported in channel catfish, Qihe crucian carp, and Darby's sturgeon after A. hydrophila challenge (Pridgeon et al. 2013; Wang et al. 2016; Zhang et al. 2018) and rohu carp after Edwardisella tarda challenge (Mohanty dan Sahoo 2010) in the immune tissues. The expression of IL1B was higher in the headkidney and spleen of susceptible fish (Figure 3; $\mathrm{p}<0.05$ ). The excessive up-regulation of IL1B and other inflammatory cytokines showed an inefficient immuneresponse and lead to severe tissue damage, oxidative stress, and higher mortality in the susceptible group (Tort 2011; Dettleff et al. 2015). Upon A. hydrophila and other bacterial infections, the HAMP gene also showed significant expression, mainly in the liver of teleost fish (Das et al. 2015; Yang et al. 2007). This pattern might be due to the liver hepatocyte as the primary site for HAMP synthesis (Neves et al. 2016). These results suggest that the LYSC and HAMP gene might play an essential role in the fish effective immune responses against $A$. hydrophila infection in African catfish. Further research regarding the SNP in the HAMP gene is the potential to be done in the future.

Based on the LYSC genotyping results by sequencing among the seven resistant and five susceptible fish, we found three genotypes at SNP2: TT, CC, and CT (Figure 4). Susceptible fish were likely had more CC genotype than resistant fish and further analyzed with qPCR-HRM analysis to identify the genotype frequencies in SNP2. The results are shown in Table 3. In the resistant group, the frequencies of TT, $\mathrm{CC}$, and TC were $27.78 \%, 5.55 \%$, and $66.67 \%$, respectively, while the frequencies of TT, CC, and TC were $16.67 \%, 27.78 \%$, and $55.55 \%$ in the susceptible group, respectively. This result is suggesting that the SNP2 may be associated with the resistance to A. hydrophila infection in African catfish. In other fish species, the polymorphism in the LYSC gene was also reported to be associated with pathogenic bacteria resistance. Two SNPs in exon 2 (position 655, CC) and intron 3 (position 934, $\mathrm{CT}$ ) of the LYSC gene reported being correlated with the big-belly disease resistance in Asian sea bass (Fu et al. 2013). The genotype $\mathrm{CC}$ at position $536, \mathrm{CC}$ at position 1200, and GG at position 140 in the Japanese flounder LYSC were reported to be correlated with the resistance to Listonela anguillarum (Liu et al. 2017).

Table 3. The Distribution of SNP2 genotypes in resistant and susceptible groups of African catfish after Aeromonas hydrophila challenge

\begin{tabular}{lcccc}
\hline Population & Genotype & N total & Percentage & p-value \\
\hline Resistant & TT & 10 & 27.78 & \\
& CC & 2 & 5.55 & \\
& TC & 24 & 66.67 & 0.035 \\
Susceptible & TT & 6 & 16.67 & \\
& CC & 10 & 27.78 & \\
& TC & 20 & 55.55 & \\
\hline
\end{tabular}




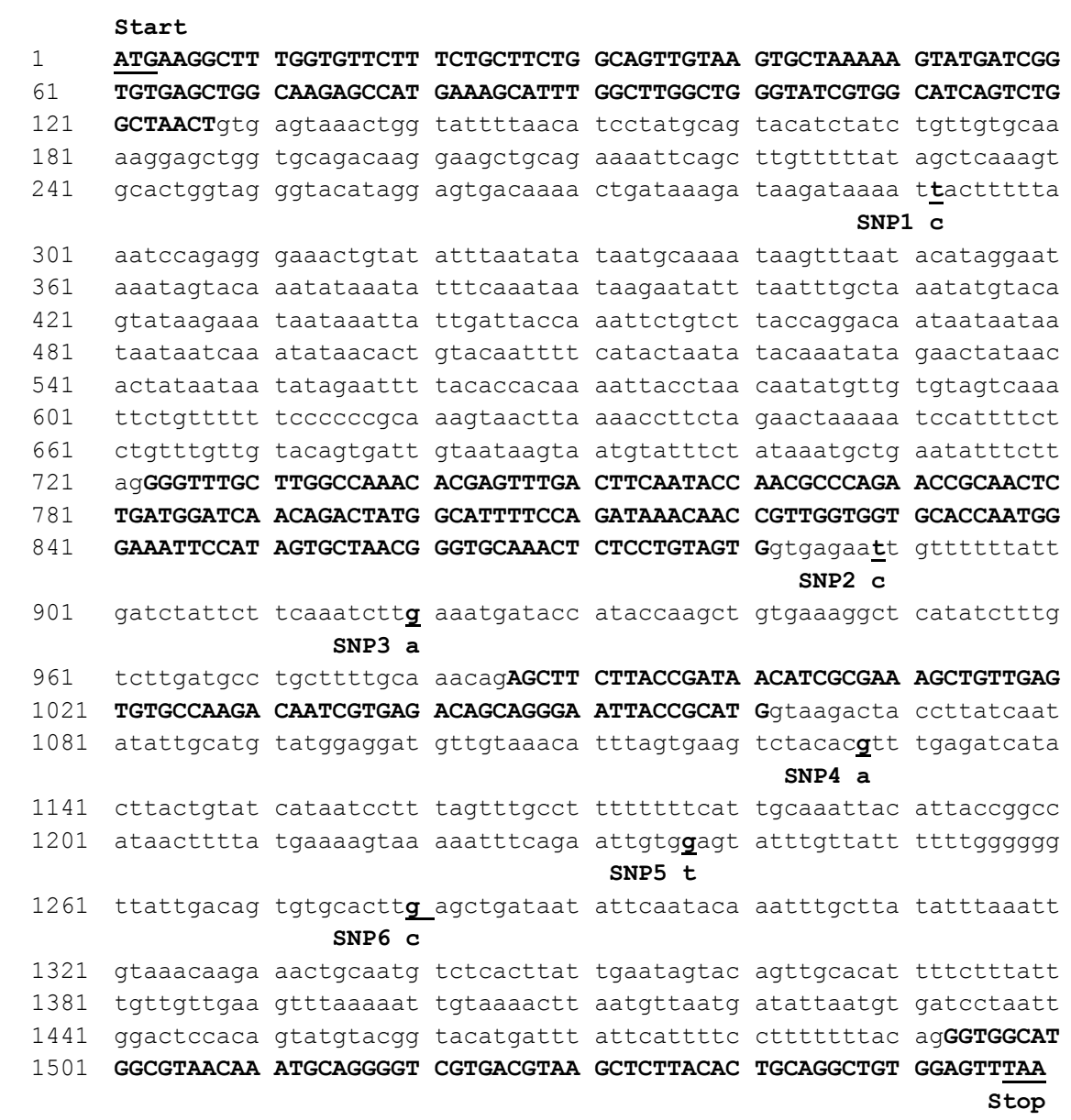

Figure 1. The gDNA sequence and the SNP position of African catfish LYSC gene. The capital letters are the exons, the small letters are the introns. Start and stop codons are underlined

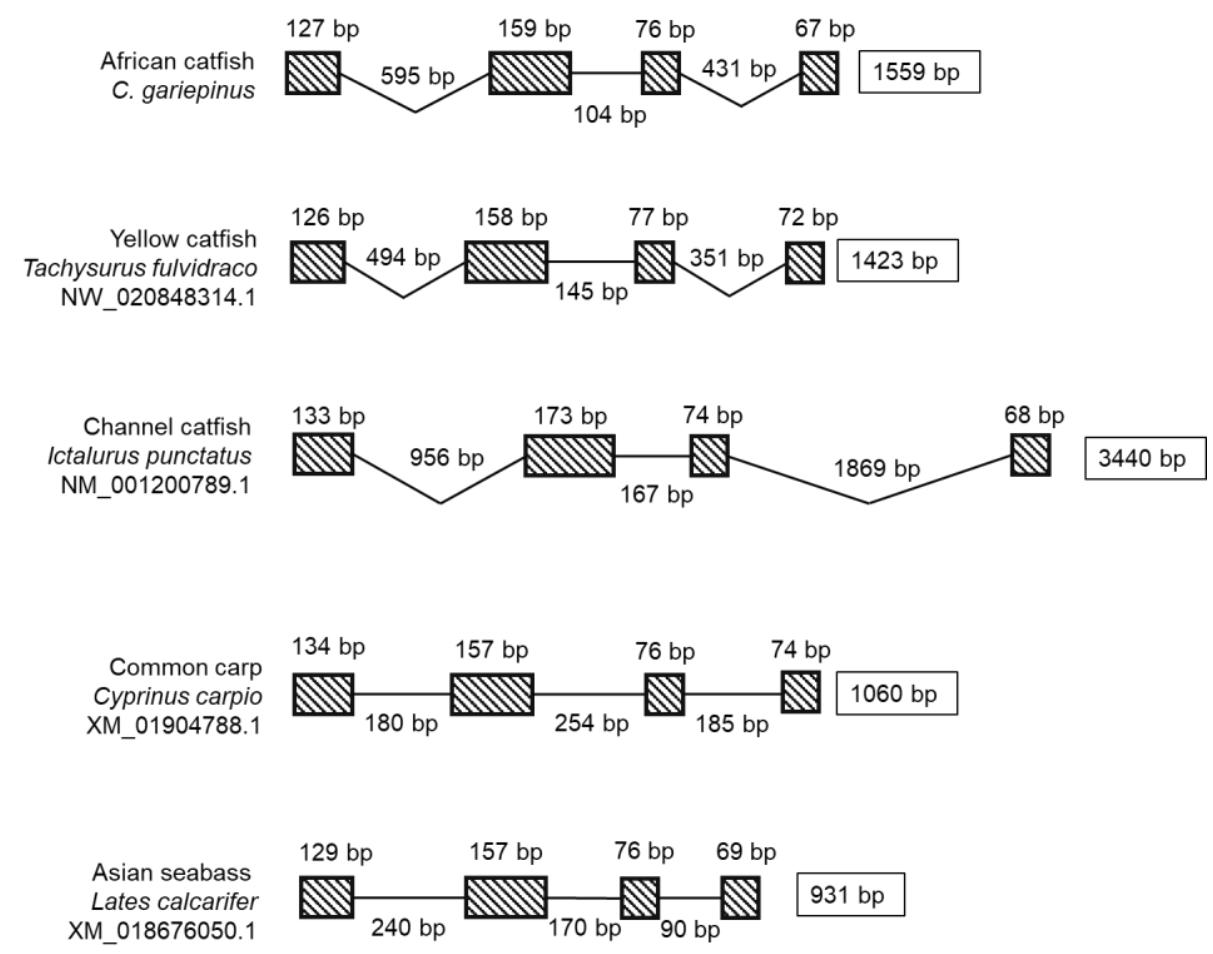

Figure 2. The LYSC gene comparison between African catfish and other fish species. Exons are shown with boxes and introns with the line. The Genbank accession numbers are included under the species name 
Liver

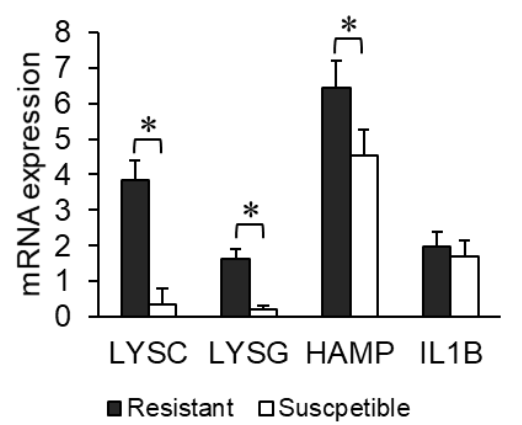

Head-kidney

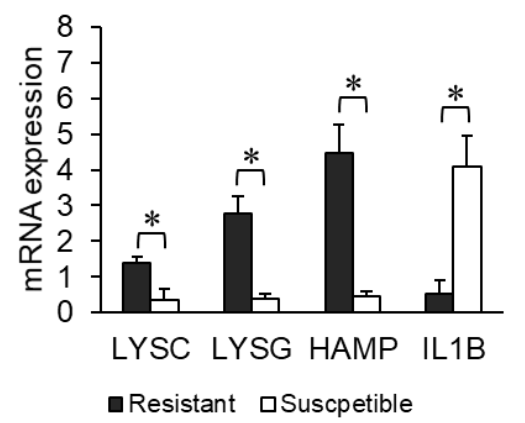

Spleen

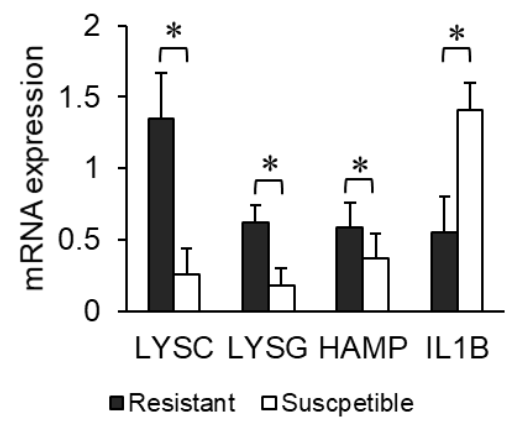

Figure 3. Relative mRNA expression levels of the LYSC and other immune-related genes of African catfish $24 \mathrm{~h}$ after A. hydrophila challenge. The $\beta$-actin gene was used for normalization and PBS control at $0 \mathrm{~h}$ as the expression calibrator. Data are shown as mean \pm SD $(\mathrm{n}=$ 4). Asterisks $(*)$ indicate the significant differences between resistant and susceptible fish $(\mathrm{p}<0.005)$.

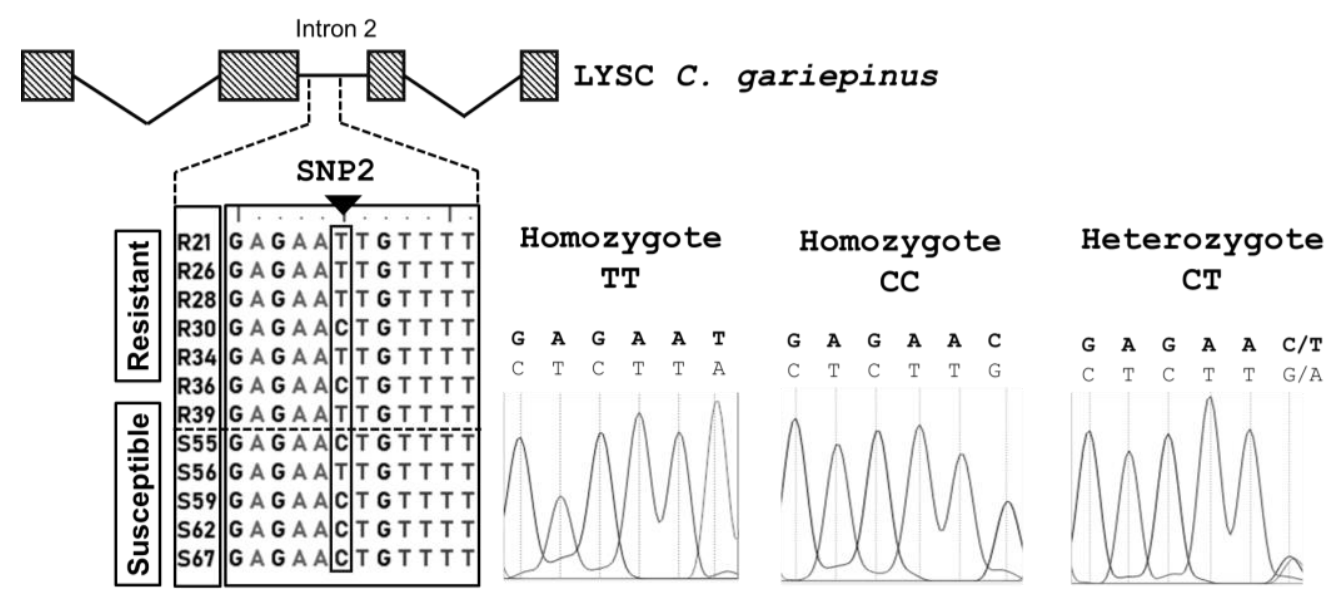

Figure 4. Genotype variation and normalized melting plots of HRM analysis at SNP2 on the resistant and susceptible African fish after the Aeromonas hydrophila challenge. Three different genotypes were identified within the population: TT, CC, and TC.

For future development, it is essential to examine and confirm the association of the SNP2 in a larger population before its application as the potential marker in the African catfish selective breeding program. Moreover, the SNP2 association with other bacterial pathogens or stress resistance and its correlation with the growth traits could also be examined. In conclusion, the LYSC gDNA sequence was identified and characterized in African catfish. The modulation of its expression in the immunetissues after A. hydrophila challenge suggests that the LYSC gene plays an essential role in A. hydrophila defense and resistance. The SNP2 found in the LYSC predicted to be associated with the resistance to $A$. hydrophila infection and may facilitate the future marker-assisted selection of the disease-resistance African catfish.

\section{ACKNOWLEDGMENTS}

There is no conflict of interest in this article. This work was supported by the Ministry of Research and Higher Education, Republic of Indonesia [grant number: PMDSU 1098/IT3.11/LT/2017] for Hasan Nasrullah and Alimuddin Alimuddin. We thank Dodi Hermawan and Dedi Supriyadi for their technical assistance in this study.

\section{REFERENCES}

Angka SL, Lam TJ, Sin YM. 1995. Some virulence characteristics of Aeromonas hydrophila in walking catfish (Clarias gariepinus). Aquaculture. $130 \quad(2-3)$ : 103-112. DOI: $10.1016 / 0044-8486$ (94)00216-B. 
Buonocore F, Randelli E, Trisolino P, Facchiano A, de Pascale D, Scapigliati G. 2014. Molecular characterization, gene structure, and antibacterial activity of a g-type lysozyme from the European sea bass (Dicentrarchus labrax L.). Mol Immunol 62 (1): 10-18. DOI 10.1016/j.molimm.2014.05.009.

Callewaert L, Michiels CW. 2010. Lysozymes in the animal kingdom. J Biosci 35 (1): 127-160. DOI: 10.1007/s12038-010-0015-5.

Das A, Mohapatra A, Sahoo Pk. 2015. Cloning and characterization of antimicrobial peptide, hepcidin in Medium carp, Puntius sarana. Int J Pept Res Ther 21: 139-147. DOI: 10.1007/s10989-014-9438-4

Dauda AB, Natrah I, Karim M, Kamarudin MS, Bichi A u H. 2018. African Catfish Aquaculture in Malaysia and Nigeria : Status, Trends, and African Catfish Aquaculture in Malaysia and Nigeria: Status, Trends, and Prospects. Fish Aquacult J 9 (1): 1-5. DOI: 10.4172/2150-3508.1000237.

Dettleff P, Bravo C, Patel A, Martinez V. 2015. Patterns of Piscirickettsia salmonis load in susceptible and resistant families of Salmo salar. Fish Shellfish Immunol 45 (1): 67-71. DOI: 10.1016/j.fsi.2015.03.039.

Ekasari J, Suprayudi MA, Wiyoto W, Hazanah RF, Lenggara GS Sulistiani R, Alkahfi M, Zairin M. 2016. Biofloc technology application in African catfish fingerling production: The effects on the reproductive performance of broodstock and the quality of eggs and larvae. Aquaculture 464: 349-356. DOI 10.1016/j.aquaculture.2016.07.013.

Di Falco F, Cammarata M, Vizzini A. 2017. Molecular characterisation, evolution and expression analysis of g-type lysozymes in Ciona intestinalis. Dev Comp Immunol 67: 457-463. DOI: 10.1016/j.dci.2016.09.010.

Fu GH, Bai ZY, Xia JH, Liu F, Liu P, Yue GH. 2013. Analysis of Two Lysozyme Genes and Antimicrobial Functions of Their Recombinant Proteins in Asian Seabass. PLoS One 8 (11): e79743. DOI: 10.1371/journal.pone.0079743.

Hanson LA, Liles MR, Hossain MJ, Griffin MJ, William G. 2014. Motile Aeromonas Septicemia. In: American Fisheries Society-Fish Health Section. Blue Book. Bethesda, Maryland.

Hikima J, Hirono I, Aoki T. 2000. Molecular cloning and novel repeated sequences of a C-type Lysozyme Gene in Japanese Flounder (Paralichthys olivaceus). : 241-247. DOI: 10.1007/s101269900028.

Liu J, Zhou N, Fu R, Cao D, Si Y, Li A, Zhao H, Zhang Q, Yu H. 2017. The polymorphism of the chicken-type lysozyme gene in Japanese flounder (Paralichthys olivaceus) and its association with resistance/ susceptibility to Listonella anguillarum. Fish Shellfish Immunol 66: 43-49. DOI: 10.1016/j.fsi.2017.05.010.

Livak KJ, Schmittgen TD. 2001. Analysis of relative gene expression data using real-time quantitative PCR and the 2- $\Delta \Delta C T$ method. Methods 25 (4): 402-408. DOI: 10.1006/meth.2001.1262.

Mohanty BR, Sahoo PK. 2010. Immune responses and expression profiles of some immune-related genes in Indian major carp, Labeo rohita to Edwardsiella tarda infection. Fish Shellfish Immunol 28 (4): 613 621. DOI: 10.1016/j.fsi.2009.12.025.
Nasrullah H, Nababan YI, Yanti DH, Hadiantho D, Nuryati S, Zairin Jr M, Eksari J, Alimuddin A. 2019. Identification and expression analysis of C-type and g-type lysozymes genes after Aeromonas hydrophila infection in African catfish. J Akuakultur Indonesia 18 (2): 1-10. DOI: 10.19027/jai.18.2.1-10.

Neves, J, Caldas, C, Ramos, MF, Rodrigues, PNS. 2016. HepcidinDependent Regulation of Erythropoiesis during Anemia in a Teleost Fish, Dicentrarchus labrax. PLoS One. 11: 1-17. DOI: 10.1371/journal.pone.0153940

Pridgeon JW, Klesius PH, Dominowski PJ, Yancey RJ, Kievit MS. 2013. Chicken-type lysozyme in channel catfish: Expression analysis, lysozyme activity, and efficacy as immunostimulant against Aeromonas hydrophila infection. Fish Shellfish Immunol 35 (3): 680688. DOI: 10.1016/j.fsi.2013.05.018.

Sahoo PK, Mukherjee SC, Sahoo SK. 1998. Aeromonas hydrophila versus Edwardsiella tarda: a pathoanatomical study in Clarias batrachus. J Aqua. 6: 57-66

Saurabh S, Sahoo PK. 2008. Lysozyme: An important defense molecule of fish innate immune system. Aquacult Res 39 (3): 223-239. DOI: 10.1111/j.1365-2109.2007.01883.x.

Shoko AP, Limbu SM, Mgaya YD. 2016. Effect of stocking density on growth performance, survival, production, and financial benefits of African sharptooth catfish (Clarias gariepinus) monoculture in earthen ponds. J Appl Aquacult 28 (3): 220-234. DOI: 10.1080/10454438.2016.1188338.

Tort L. 2011. Stress and immune modulation in fish. Dev Comp Immunol 35 (12): 1366-1375. DOI: 10.1016/j.dci.2011.07.002

Wang M, Zhao X, Kong X, Wang L, Jiao D, Zhang H. 2016. Molecular characterization and expressing analysis of the C-type and g-type lysozymes in Qihe crucian carp Carassius auratus. Fish Shellfish Immunol 52: 210-220. DOI: 10.1016/j.fsi.2016.03.040.

Wang R, Feng J, Li C, Liu S, Zhang Y, Liu Z. 2013. Four lysozymes (one $\mathrm{C}$-type and three g-type) in catfish are drastically but differentially induced after bacterial infection. Fish Shellfish Immunol 35 (1): 136145. DOI: 10.1016/j.fsi.2013.04.014.

Wei S, Huang Y, Huang X, Cai J, Wei J, Li P, Ouyang Z, Qin Q. 2014. Molecular cloning and characterization of a new G-type lysozyme gene (Ec-lysG) in orange-spotted grouper, Epinephelus coioides. Dev Comp Immunol 46 (2): 401-412. DOI: 10.1016/j.dci.2014.05.006.

Yang M, Wang K, Chen J, Du H, Li S. 2007. Genomic organization and tissue-specific expression analysis of hepcidin-like genes from black porgy (Acanthopagrus schlegelii B.). Fish Shellfish Immunol 23: 1060-1071

Yarahmadi P, Miandare HK, Fayaz S, Caipang CMA. 2016. Increased stocking density causes changes in expression of selected stress-and immune-related genes, humoral innate immune parameters, and stress responses of rainbow trout (Oncorhynchus mykiss). Fish Shellfish Immunol 48: 43-53. DOI: 10.1016/j.fsi.2015.11.007.

Zhang S, Xu Q, Boscari E, Du H, Qi Z, Li Y, Huang J, Di J, Yue H, Li C, et al. 2018. Characterization and expression analysis of g-and C-type lysozymes in Dabry's sturgeon (Acipenser dabryanus). Fish Shellfish Immunol 76: 260-265. DOI: 10.1016/j.fsi.2018.03.006 


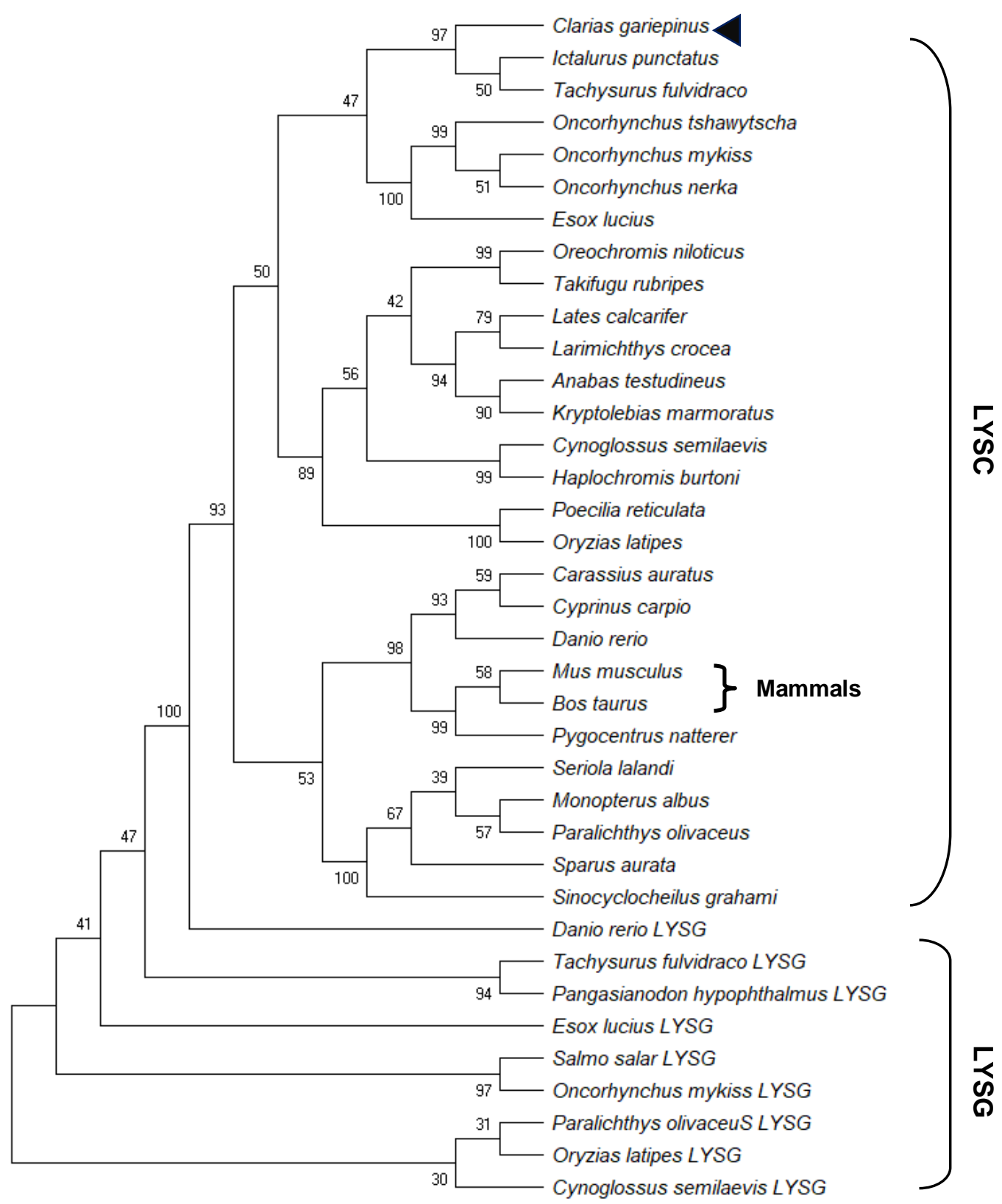

Figure S1. Phylogenetic tree of LYSC gDNA sequence of African catfish and other species. The tree was constructed using the neighbor-joining method with $1000 \mathrm{x}$ bootstraps in MEGA X software 